\title{
Detection of white spot disease virus infection in wild-caught greasy back shrimp, Metapenaeus ensis (de Haan) in Taiwan
}

\author{
C. S. Wang, Y. J. Tsai, G. H. Kou and S. N. Chen* \\ Department of Zoology, National Taiwan University, Taipei, Taiwan 107
}

(Received August 30, 1996)

\begin{abstract}
The present study attempted to investigate the white spot disease virus (WSDV) infection in the wild-captured greasy back shrimp, Metapenaeus ensis. The shrimp showed no symptom of white spots in the carapace that usually occur in the other cultured shrimps. In histopathological studies, the hypertrophied nuclei of the necrotic cells were found in the various tissues originated from ectoderm and mesoderm which were similar to those observed in the giant tiger shrimp (Penaeus monodon) and kuruma shrimp ( $P$. japonicus). Neither occlusion bodies nor cytoplasmic inclusions were found in the infected greasy back shrimp. Transmission electron micrographs revealed rod-shaped and enveloped viruses in the hypertrophied nuclei. The virions measured $221 \pm 6 \mathrm{~nm}$ by $107 \pm 7 \mathrm{~nm}$ in size, and were comparatively smaller than those found in WSDV infected $P$. monodon and $P$. japonicus. When in situ hybridization using DIG-labelled WSDV probe was used, positive reaction was found in the hypertrophied nuclei. DNA amplification by polymerase chain reaction (PCR) with two oligonucleotide primers developed in our laboratory demonstrated that the virus found in $M$. ensis is genetically similar to WSDV in the other penaeid shrimp.
\end{abstract}

Key words: white spot disease, greasy back shrimp, polymerase chain reaction(PCR), in situ hybridization, white spot disease virus

In Taiwan, the main cultured shrimp are giant tiger shrimp (Penaeus monodon Fabricius), kuruma shrimp ( $P$. japonicus Bate), red-tail shrimp ( $P$. penicillatus Alcock) and greasy back shrimp (Metapenaeus ensis de Haan). Annual production of the greasy back shrimp are approximately 830 MT (1994). The investigation on the epizootic about the greasy back shrimp are very rare.

Since 1992, outbreaks of a new disease resulting mass mortality among cultured shrimp occurred in Taiwan. The disease was characterized by the presence of white spots on the inside surface of the carapace. The previous studies suggested that a unassigned ds-DNA virus is the causative agent for this disease (Chou et al., 1995; Wang et al., 1996), and was named as white spot disease virus (WSDV) (Chen, 1995). The WSDVinfected shrimp include $P$. monodon, $P$. japonicus and $P$. penicillatus. However, the past investigations on WSDV only emphasized on cultured shrimp, and ignored the wild-captured species. The present study describes the WSDV infection in the randomly sampled wildcaptured of greasy back shrimp using biotechnology.

* Correspondence author: Professor S. N. Chen, Department of Zoology, National Taiwan University

\section{Materials and Methods}

\section{Source of specimens}

The greasy back shrimp were collected from Pingtung located in southern Taiwan, with size ranging from $20 \mathrm{~g}$ to $25 \mathrm{~g}$. Thirty experimental shrimp were processed for histopathological studies, transmission electron microscopic studies, in situ hybridization and polymerase chain reaction (PCR) examination for WSD virus infection.

\section{Histopathological studies}

Preparation of the specimens for normal histology was performed according to those described by Bell and Lightner (1988). The specimens were preserved in Davidson's fixative for $48 \mathrm{hr}$. The fixed tissues were dehydrated with series of ethanol and embedded in paraffin. Sections of 5-7 $\mu \mathrm{m}$ in thickness were cut and stained with hematoxylin and eosin (H\&E) and used in in situ hybridization as described in the following section.

\section{Transmission electron microscopic studies}

In order to perform the observation using transmission electron microscope, pieces of lymphoid organ, gill and 
stomach were sampled from affected shrimp and fixed in $2.5 \%$ cold glutaraldehyde in $0.2 \mathrm{M}$ Sorensen's phosphate buffer (pH. 7.2) for $1 \mathrm{hr}$. After several rinses with the buffer solution, the samples were post-fixed in $1 \% \mathrm{OsO}_{4}$ for $1 \mathrm{hr}$. Subsequently, the tissues were dehydrated with series of ethanol and embedded in L. R. White resin (London Resin Company Melbourne). Ultrathin sections were cut with ultramicrotome (Sorvall MT-5000) and stained with uranyl acetate and lead citrate, and observed with a transmission electron microscope (HITACHI H-600) at 75KV.

\section{DNA probe and labelling}

Partial genomic fragment of WSDV was enriched by using random amplification of polymorphic DNA technique, then subcloned into pGEM T plasmid. The clone nominated as TS6 was chosen as probe for the detection of WSDV genome (unpublished). Two primers 6-2F, 5'-AGCAGAGGATGATATCGTAC-3' and 6-1R, 5'-CAACACTATCATCACAGTCG-3' were designed base on the nucleotide sequence of TS6. Nonradioactively labelled probe of approximate 700bp was prepared by PCR with WSDV DNA as template, 6-2F and $6-1 \mathrm{R}$ as primers and with substrate containing DIG11-dUTP, by utilizing the procedures suggested by the manufacture (Boehringer Mannheim).

\section{In situ hybridization}

The detection of WSDV were performed by in situ hybridization using DIG-11-dUTP labelled probe according to the previously described by Wang et al. (1996). The sections were de-paraffined and rehydrated in a series of graded ethanol, followed by digestion with proteinase $\mathrm{K}(100 \mu \mathrm{g} / \mathrm{m} l)$ and the fixed in cold $4 \%$ formaldehyde. The sections were heated to $95^{\circ} \mathrm{C}$ for $10 \mathrm{~min}$ and allowed to hybridize for $12 \mathrm{hr}$ at $42^{\circ} \mathrm{C}$ in probe hybridization solution containing $50 \%$ formamide, $1 \mu \mathrm{g} / \mathrm{m} l$ DIG-labelled probe, $0.2 \mathrm{mg} / \mathrm{m} l$ sonicated salmon sperm DNA, 5\% dextran sulfate, $4 \times$ SSC ( $0.6 \mathrm{M}$ sodium chloride, $60 \mathrm{mM}$ sodium citrate, $\mathrm{pH}$. 7.0). The experiment was carried out using alkaline phosphatase-labelled anti-DIG antibody and substratesolution (NBT and X-phosphate). After counterstained by using eosin $\mathrm{Y}$, the sections were then dehydrated and mounted with Entellan (Merck), and examined under bright field microscopy (Olympus MI-1).

\section{Extraction of WSDV DNA from M. ensis}

The stomach was removed and dissected from the greasy back shrimp, and homogenized in lysis buffer (50
mM Tris- $\mathrm{HCl}, 10 \mathrm{mM} \mathrm{NaCl}, 2 \%$ SDS, 10 mM EDTA, proteinase $\mathrm{K} 100 \mu \mathrm{g} / \mathrm{ml}$ ) for $3 \mathrm{hr}$ at $56^{\circ} \mathrm{C}$. The DNA was extracted by the phenol method as described by Sambrook et al. (1989).

\section{PCR amplification and analysis of products}

6-2F and 6-1R primers as described above were used for PCR. The amplifica-tion procedure were carried out in a $50 \mu \mathrm{l}$ reaction mixture containing $10 \mathrm{mM}$ Tris$\mathrm{HCl}$ (pH 8.0), $50 \mathrm{mM} \mathrm{KCl}, 1.5 \mathrm{mM} \mathrm{MgCl}_{2}, 0.1 \%$ Triton $\mathrm{X}-100,0.2 \mathrm{mM}$ of each dNTP, $100 \mathrm{pmol}$ of each primer, 1 unit of Taq DNA polymerase and 50-100 ng DNA templates. A drop of mineral oil was added to cover the mixture. The amplification was performed in a PTC-100 DNA thermal cycler (MJ Research Inc.) $95^{\circ} \mathrm{C}$ for $5 \mathrm{~min}$, and then 50 cycles $\left(95^{\circ} \mathrm{C}\right.$ for $30 \mathrm{sec}, 55^{\circ} \mathrm{C}$ for $30 \mathrm{sec}$, and $72^{\circ} \mathrm{C}$ for $1 \mathrm{~min}$ ), plus a final $5 \mathrm{~min}$ extension at $72^{\circ} \mathrm{C}$ after the 50 cycles. The PCR products were analyzed in $1.5 \%$ agarose gels containing ethidium bromide at a final concentration of $0.5 \mu \mathrm{g} / \mathrm{ml}$ and visualized under UV transilluminator. The PCR product derived from WSD virus infected $P$. monodon was used as the positive control.

\section{Results}

In this experiment, 30 wild-captured and sex matured greasy back shrimp were sampled. All the shrimp did not show the typical syndrome of white spot disease that usually observed in the penaeid shrimp such as $P$. monodon, $P$. japonicus and $P$. penicillatus. In routine histological studies, 6 shrimps revealed the cell degeneration characterized by hypertrophied nuclei in the various tissues originated from mesoderm and ectoderm. The abnormal cells were found in stomach, lymphoid organ, antennal gland, gill and hematopoietic tissue (Figs. 1-3). No occlusion body and cytoplasmic inclusion was detected.

Under transmission electron microscopical observation, many rod-shaped, enveloped virions were observed in the hypertrophied nuclei of the cells (Figs. 4-5). The virions measured $221 \pm 6 \mathrm{~nm}$ in length and $107 \pm 7 \mathrm{~nm}$ in width $(n=6)$. In comparison the virions detected in the greasy back shrimp was smaller than WSDV found in the giant tiger shrimp and kuruma shrimp (Table 1). In some hypertrophied nuclei, the immature viruses with empty capsid, capsid originator, necleocapsid and circular envelope were detected in the nucleoplasm (Fig. 5). This observation indicates that the viral multiplication are undertaken in the nucleus. 

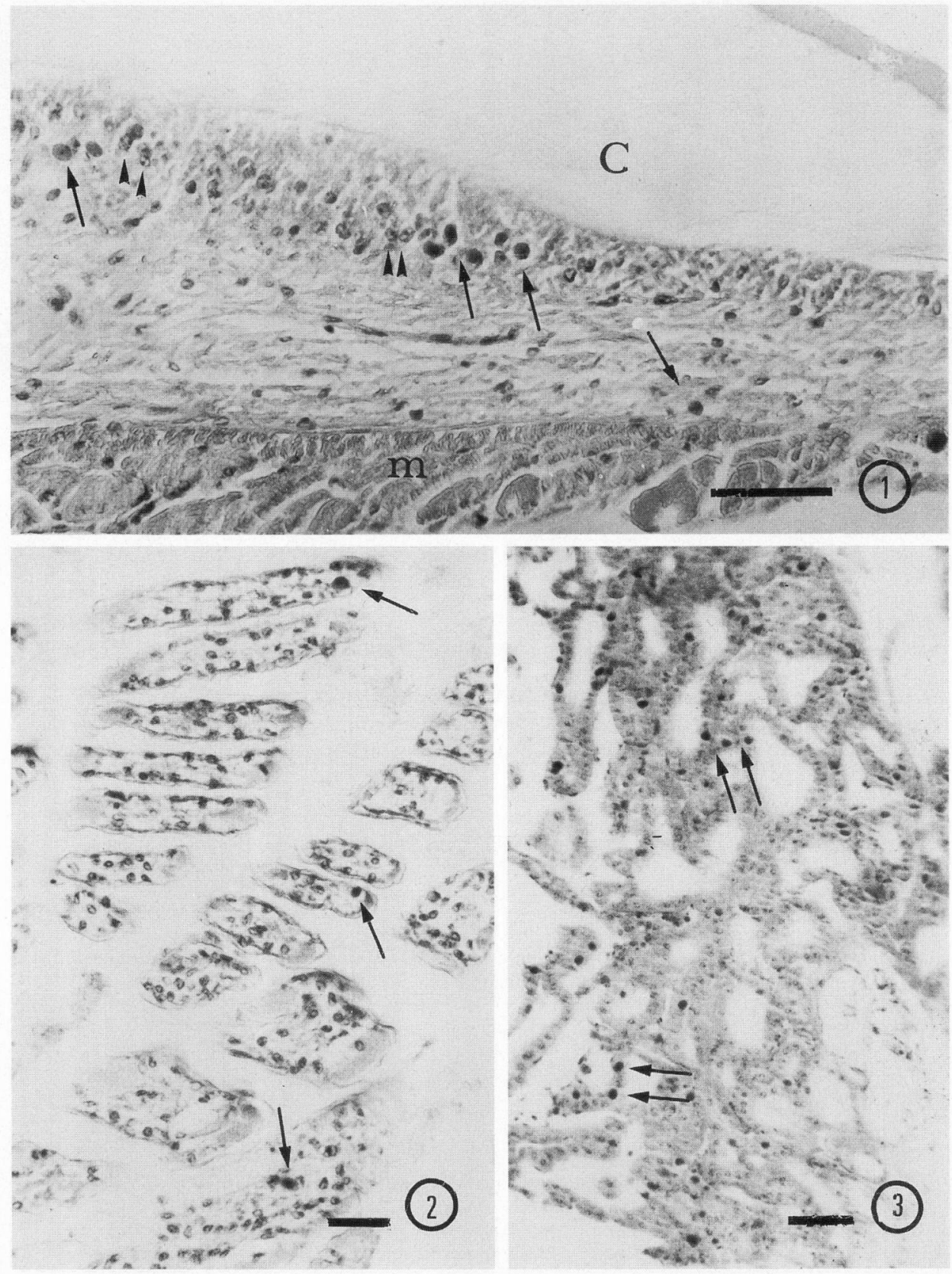

Figs. 1-3. Photomicrographs of various tissues from the WSDV-infected greasy back shrimp. Arrows indicating the WSDV infected hypertrophied nuclei, H\&E stain. 1. Stomach tissue. Arrowheads showing the normal nuclei. C: cuticle, m: muscle. Bar $=50 \mu \mathrm{m}$. 2. Gill tissue. Bar $=25 \mu \mathrm{m}$. 3. Antennal gland. Bar=50 $\mu \mathrm{m}$.

Using in situ hybridization, the DIG-11-dUTP labelled WSDV DNA probe successfully detected the virus in the hypertrophied nuclei of infected greasy back shrimp
(Table 2). The positive reaction was recognized as blue purple precipitate in the hypertrophied nuclei (Figs. 67). The results obtained by in situ hybridization are 

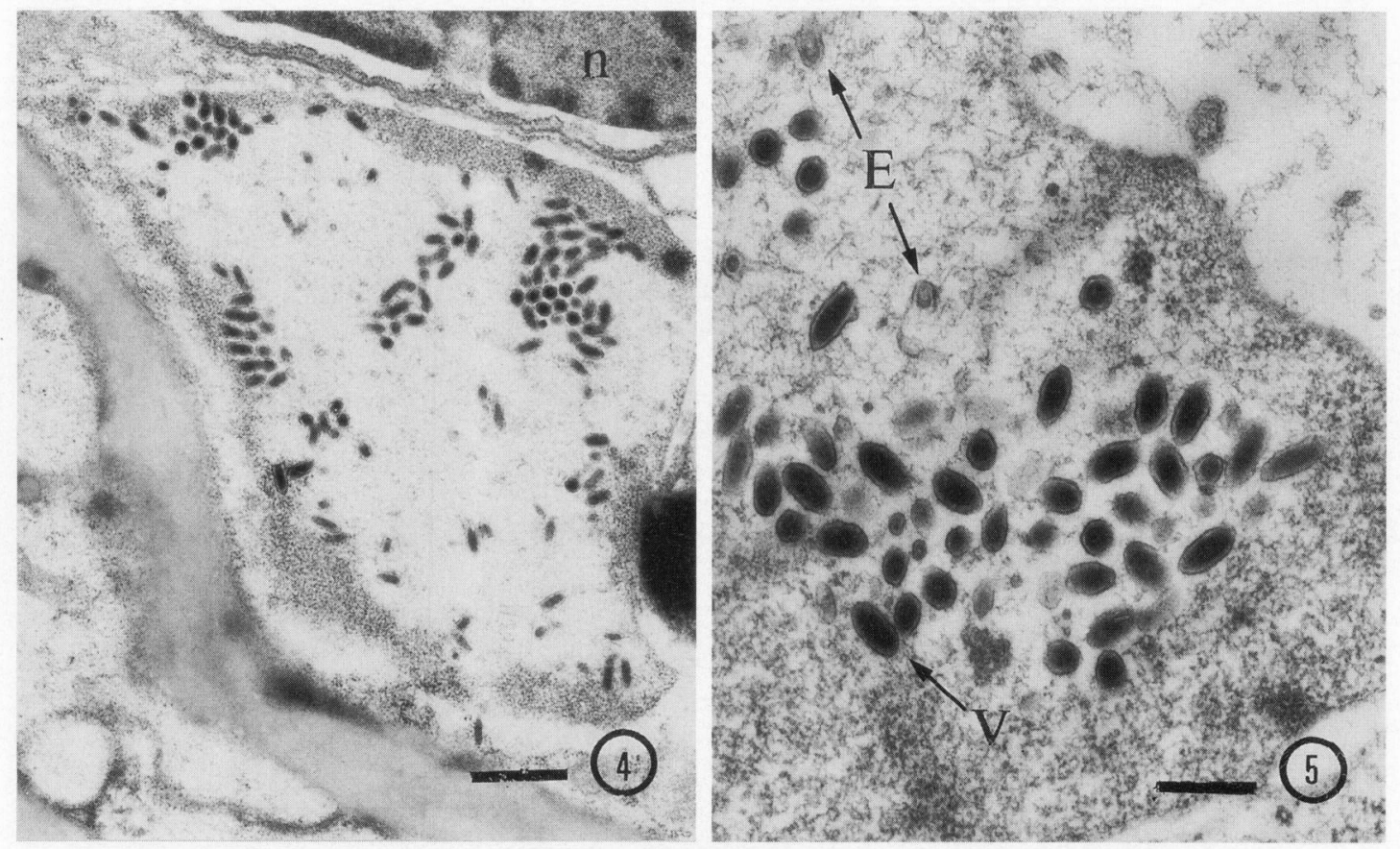

Figs. 4-5. Electron micrographs of the stomach from the WSDV-infected greasy back shrimp. 4. Viral particle in the hypertrophied nucleus, n: normal nucleus. Bar=670 nm. 5. High magnification of virus showing various assembly stages, E: empty capsid, V: matured virion with the nucleocapsid surrounded by envelope. Bar=285 nm.

Table 1. Morphometric comparison of WSD virus from $P$. monodon, $P$. japonicus and $M$. ensis

\begin{tabular}{lccc}
\hline \hline & P. monodon & P. japonicus & M. ensis \\
\hline TEM sections & $270 \times 80 \mathrm{~nm}^{\mathrm{a}}$ & $330 \times 87 \mathrm{~nm}^{\mathrm{b}}$ & $221 \times 107 \mathrm{~nm}^{\mathrm{c}}$ \\
Negative stained & $250-380 \times 70-150 \mathrm{~nm}^{\mathrm{d}}$ & - & - \\
\hline
\end{tabular}
a: Chen, 1995
b: Chou et al., 1995
c: The present paper
d: Wang et al., 1995

Table 2. Comparison of efficacy of different methods for the diagnosis of WSDV in Metapenaeus ensis

\begin{tabular}{lcccc}
\hline \hline & Histopathology & Electron microscopy & PCR & In situ hybridization \\
\hline WSDV infection & $6 / 30^{\mathrm{a}}$ & $2 / 6$ & $10 / 30$ & $10 / 30$ \\
\hline
\end{tabular}

a: positive reaction nubmer/examination number

also similar to those observed in $P$. monodon and $P$. japonicus as described previously (Wang et al., 1996).

DNA extracted from the stomach of the greasy back shrimp were utilized as template DNA for PCR assay.
The amplification results by using WSDV DNA primers demonstrated that the greasy back shrimp were infected by WSD virus (Fig. 8). Figure 8 , shows a 700 bp product (lane 2) which same as the results obtained WSD 

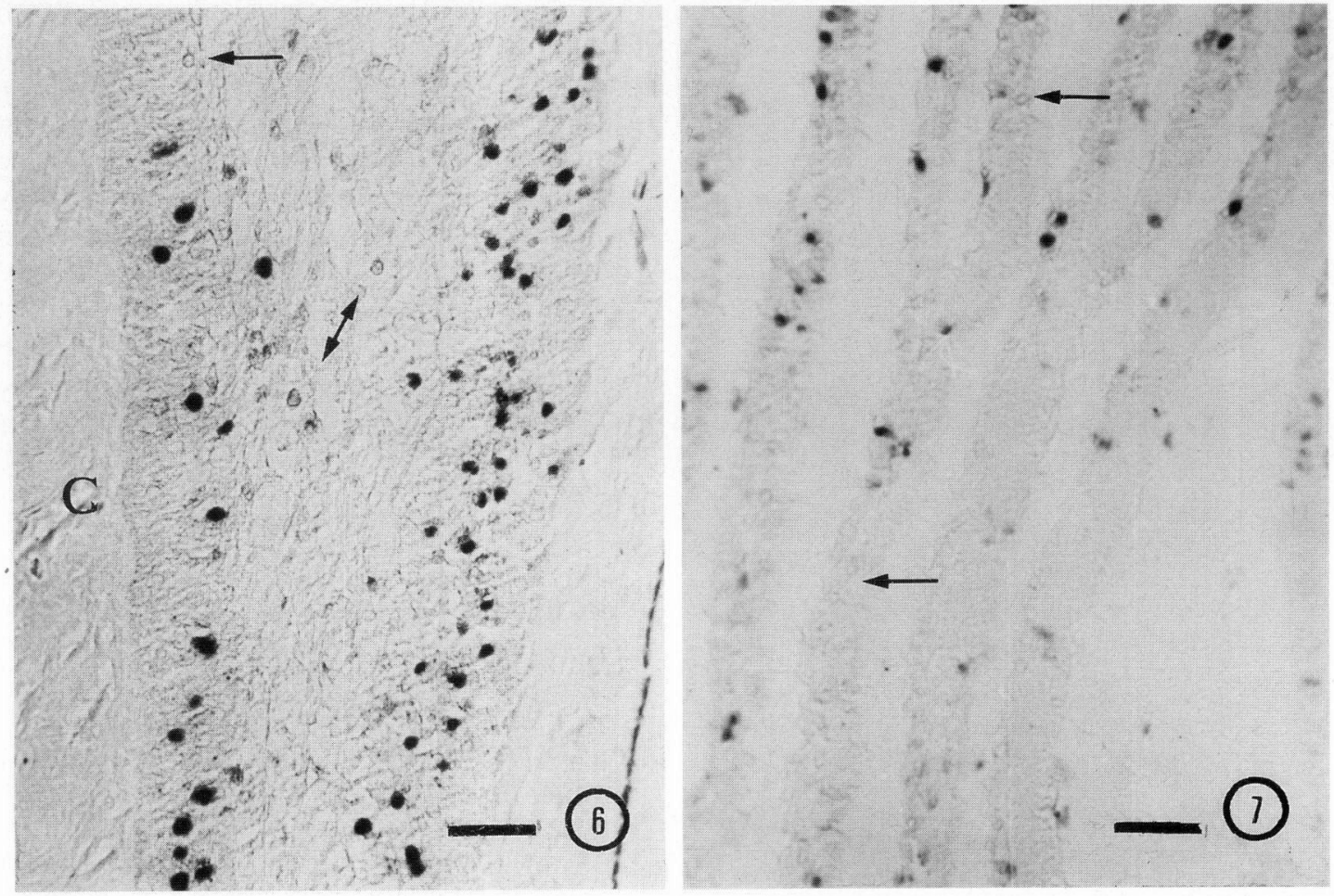

Figs. 6-7. Photomicrographs of WSDV-infected stomach and gill of greasy back shrimp using in situ hybridization, positive reaction showing dark precipitation in the infected cells. Note: arrows indicate the normal nuclei. Probe hybridization plus eosin Y counterstain. Bar=25 $\mu$ m. 6. Stomach. 7,. Gill tissue.

virus DNA as template (lane 1). No product at $700 \mathrm{bp}$ was present for healthy greasy back shrimp that had been confirmed by histological and electron microscopical observation.

\section{Discussion}

The epizootic of white spot disease has been reported in Japan, Taiwan and several Asian countries (Chou et al., 1995; Inouye et al., 1996; Nakano et al., 1994; Takahashi et al., 1994). Outbreak of this disease resulted mass mortality among cultured shrimps such as the giant tiger shrimp ( $P$. monodon), kuruma shrimp $(P$. japonicus), red-tail shrimp ( $P$. penicillatus) (Chen, 1995). However, no work has been done on the greasy back shrimp (M. ensis). The specific gross syndrome of WSD is the presence of white spots on the inside surface of the carapace (Wang et al., 1996). The present study demonstrates the first discovery of WSDV infection in the wild-captured greasy back shrimp. Although experimental shrimps did not show the characterized clinical signs of white spot, the present results on histopathology, in situ hybridization and PCR show WSDV infections on those shrimps. This result may suggest that the WSDV infection asymptomatically occurs in the shrimp which can be used as brookstock. Since the infected shrimp may be utilized for artificial spawning, transfer of WSDV to their offspring is possible.

Although definite shrimp viral infection relies on the observation of light and electron microscopy, these techniques are very time consuming. In recent several years, molecular probes have been developed for the detection of shrimp virus, so that rapid detection techniques such as in situ hybridization and PCR amplification for the viral DNA detection in shrimp become possible (Kimura et al., 1996; Lo et al., 1996; Lu et al., 1995; Wang et al., 1996). Using electron microscopical observation, it was found that wildcaptured mature greasy back shrimp infected by a non- 


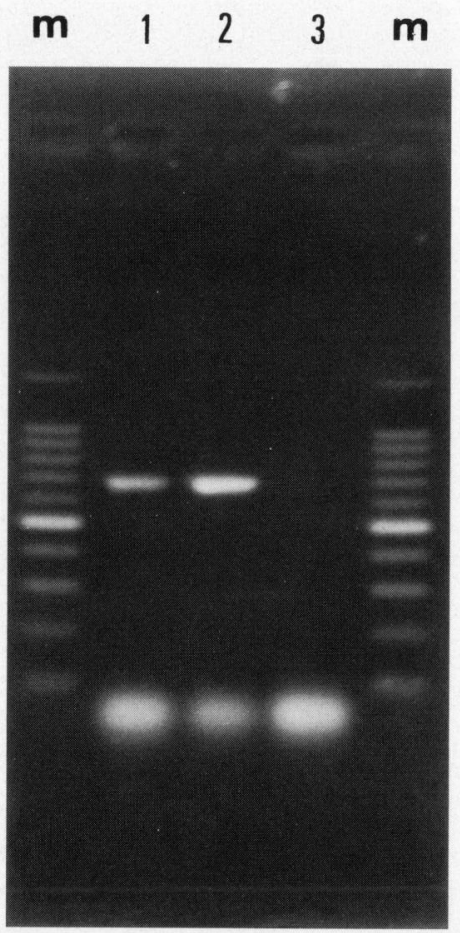

Fig. 8. Detection of the products of polymerase chain reaction (PCR) from various sources. Templates were prepared from WSDV-infected $P$. monodon (lane 1), suspected WSDV-infected M. ensis (lane 2) and uninfected $M$. ensis (lane 3). m: DNA molecular marker (100 base pair ladder).

occluded, rod-shaped virus which was smaller than the WSDV in P. monodon (Table 1). Similarity, Lightner (1993) also reported that various size of BP (Baculovirus penaei) virus were found in different species of penaeid shrimp. It is demonstrated that similar virus may reveal a different particle size in various species of host. In addition, PCR amplification using two primers according to WSDV gene sequence confirmed that this virus is genetically related to WSDV (Fig. 8). In according with the morphological and genetic characterisitics, the virus found in greasy back shrimp in this experiment may be similar to WSDV found in $P$. monodon and P. japonicus.

In the past, the investigation on the disease of the greasy back shrimp was very rare, especially on the virological research. Previously, Momoyama et al. (1996) described that the greasy back shrimp were refractory to the baculoviral mid-gut gland necrotic virus (BMNV). However, Chen et al. (1989) found that this shrimp could be infected by Penaeus monodon-type baculovirus (MBV). Recently, Kiruma et al. (1996) reported that a PCR positive reaction was obtained from Metapenaeus monoceros collected from kuruma shrimp culture pond in which PAV (penaeid acute viremia) of kuruma shrimp occurred. Greasy back shrimp are naturally abundant species in southeast Asia and usually polycultured with $P$. monodon, milkfish and seaweed in Taiwan. Occurrence of WSDV infection in wildcaptured mature greasy back shrimp suggests a wide host range of this virus. Infection of WSDV through naturally infected host to the cultured shrimps in therefore not neglectful.

\section{Acknowledgements}

This work was supported by the National Science Council under Grant No. NSC85-2311-B002-039, ROC.

\section{References}

Bell, T. A. and D. V. Lightner (1988): A handbook of normal penaeid shrimp histology. World Aquaculture Society, Baton Rouge, Louisiana, USA.

Chen, S. N. (1995): Current status of shrimp aquaculture in Taiwan. In "Swimming through troubled water, Procceding of the special session on shrimp farming, Aquaculture' 95". (ed. by C. L. Browdy and J. S. Hopkins), World Aquaculture Society. Baton Rouge, Louisiana, USA, pp. 29-34.

Chen, S. N., C. F. Lo, S. M. Liu and G. H. Kou (1989): The first identification of Penaeus monodon baculovirus (MBV) in the cultured sand shrimp, Metapenaeus ensis, Bull. Eur. Ass. Fish Pathol., 9, 62-64.

Chou, H. Y., C. Y. Huang, C. H. Wang, H. C. Chiang and C. F. Lo (1995): Pathogenicity of a baculovirus infection causing white spot syndrome in the cultured penaeid shrimp in Taiwan. Dis. Aquat. Org., 23, 165-173.

Kimura, T., K. Yamano, H. Nakano, K. Momoyama, M. Hiraoka and K. Inouye (1996): Detection of penaeid rod-shaped DNA virus (PRDV) by PCR. Fish Pathol., 31, 93-98.

Inouye, K., K. Yamano, N. Ikeda, T. Kimura, H. Nakano, K. Momoyama, J. Kobayashi and S. Miyajima (1996): The penaeid rod-shaped DNA virus (PRDV), which causes penaeid acute viremia (PAV). Fish Pathol., 31, 39-45.

Lightner, D. V. (1993): Diseases of cultured penaeid shrimp, In "CRC handbook of mariculture, 2nd ed, Vol 1, Crustacean aquaculture" (ed. by J. P. McVey). C CRC Press, Boca Raton, pp. $393-486$.

Lo, C. F., J. H. Leu, C. H. Ho., C. H. Chen, S. E. Peng, Y. T. Chen, C. M. Chou, P. Y. Yeh, C. J. Huang, H. Y. Chou, C. H. Wang and G. H. Kou (1996): Detection of baculovirus associated with white spot syndrome (WSBV) in penaeid shrimps using polymerase chain reaction. Dis. Aquat. Org., 25, 133-141.

Lu, C. C., K. F. J. Tang, G. H. Kou and S. N. Chen (1995): 
Detection of Penaeus monodon-type baculovirus (MBV) infection in Penaeus monodon Fabricius by in situ hybridization. J. Fish Dis., 18, 337-345.

Momoyama, K. and T. Sano (1996): Infectivity of baculoviral mid-gut gland necrosis virus (BMNV) to larvae of five crustacean species. Fish Pathol., 31, 81-85.

Nakano, H., H. Koube, S. Umesawa, K. Momoyama, M. Hiraoka, K. Inouye and N. Oseko (1994): Mass mortalities of cultured kuruma shrimp, Penaeus japonicus, in Japan in 1993: epizootiological survey and infection trial. Fish Pathol., 29, 135-139.

Sambrook, J., E. F. Fritsch and T. Maniatis (1989): Molecular cloning, a laboratory manual. 2nd. Cold Spring Harbor Laboratory Press, Cold Spring Harbor, New York.
Takahashi, Y., T. Itami, M. Kondo, M. Maeda, R. Fujii, S. Tomonaga, K. Supamattaya and S. Boonyaratpalin. (1994): Electron microscopic evidence of bacilliform virus infection in kuruma shrimp (Penaeus japanicus). Fish Pathol., 29, 121-125.

Wang, C. H., C. F. Lo., J. H. Leu, C. M. Chou, P. Y. Yeh, H. Y. Chou, M. C. Tung, C. F. Chang, M. S. Su and G. H. Kou (1995): Purification and genomic analysis of baculovirus associated with white spot syndrome (WSBV) of Penaeus monodon. Dis. Aquat. Org., 23, 239-242.

Wand, C. S., Y. J. Tsai, G. H. Kou and S. N. Chen (1996): Detection of white spot disease virus (WSDV) infection in shrimp using in situ hybridization. J. Invertebr. Pathol. (in press) 